By FELIX E. HIRSCH

\title{
The Use of the Book Collection in the Teaching Program of a Progressive College
}

Felix E. Hirsch is librarian and instructor at Bard College. In this article he shows how three progressive colleges seek to teach with books-thus vitalizing and individualizing their curricula.

COME Years ago President Wriston of $\mathcal{S}$ Brown University made a very telling comparison. "When the doctor," he said, "wants to know the general state of your health, he takes your temperature and your pulse. In much the same way I regard the two-week-book circulation as the most significant single indication of the intellectual well-being of the institution." If that is true, the progressive colleges in America seem to enjoy an unusually fine state of health, for their figures of student reading per capita are higher than those of almost any other college.

Branscomb in his recent study Teaching with Books points to one of these progressive institutions, Bennington College, as an example for his thesis that the students will use the library where the curriculum and method of instruction are planned with that expectation. He gives the circulation statistics for Bennington, which since 1934 have exceeded annually 55 books (1939/40:65) and 9 reserve books per capita, although the students reside on the Bennington campus only thirty weeks a year. These figures are impressive, indeed, if you hold them against the average circulation in American colleges, which Branscomb puts at only 12 books and 50 to 60 reserve books per capita. Two other progressive colleges in the East, Sarah Lawrence and Bard, have had equally satisfactory experiences with student reading. At Sarah Lawrence College the annual book circulation per student has ranged from 43 to 50 volumes in recent years. The annual figure for two-week books at Bard College has been above 70 per student during the last five years; in $1936 / 37$ and $1938 / 39$ it approached $8 \mathrm{o}$. The number of overnight reserves, meanwhile, sank from 33 to about 10 per capita.

Since little has been published thus far about the relation between the book collection and the teaching program in progressive colleges, I shall give here some reflections based on more than four years of my experience as librarian and instructor at Bard College. Valuable suggestions for this paper have also been received from the librarians of the other two Eastern progressive colleges, Mrs. Leslie and Miss Stone. Sarah Lawrence College in Bronxville, N.Y., was the first to appear on the horizon about twelve years ago. It offered “ $A$ New Design for Women's $E d u$ - 
cation," as President Constance Warren calls her recent book, which is a lively exposition of progressive college methods in action. A few years later, in 1932, Bennington College was established in Vermont; it carries out similar, but by no means identical ideas in the field of women's education. They may be summed up in the following sentence taken from a Bennington College bulletin: "That the college should accustom its students to the habit of engaging voluntarily in learning rather than of submitting involuntarily at certain periods to formal instruction." Bard College, the only boys' college in this group, has served as an experimental unit of Columbia University since 1934; it grew out of a complete reorganization of the old St. Stephen's College. 'The man who brought about the educational change, Dr. Donald G. Tewksbury, had taught before at Sarah Lawrence College, and the present Dean, Dr. Charles Harold Gray, came from Bennington College. Thus there are certain close ties between the three institutions.

\section{Quality of the Book Collections}

Before we can investigate the relation between educational programs and use of the library, two important questions must be answered. The first is: Would it be possible to explain the high reading figures in these three progressive colleges to a considerable extent by the unusual quality of their book collections? I doubt it. Although all three of them received generous aid from the Carnegie Corporation in the process of building up their libraries, none of them can compare with those of some well-endowed conservative colleges. Sarah Lawrence and Bennington have excellent modern collections, but they are certainly not large. /Sarah Law- rence has more than thirty-four thousand volumes while Bennington is approaching twenty thousand, and they have no ambition to rival their wealthier competitors. As President Robert D. Leigh of Bennington (also Acting Dean of Bard College in 1939) put it in the foreword to the first annual report of his librarian: "Our library is designed primarily to serve as a reading room for a working collection of books. Clearly it is not intended to duplicate the great university or metropolitan research libraries." Bard, having deeper roots in the past, has a richer collection, containing more than sixty-one thousand volumes; it is strong in the social sciences and the humanities. With a maximum enrollment of 150 to 160 students it has more than four hundred books at the disposal of each student.

Further, the high reading figures of these three progressive colleges cannot be explained by the attractiveness of the library buildings or a particularly shrewd arrangement of the collections. The buildings which house the libraries at Sarah Lawrence and Bennington are modern and rather well equipped. They convey a pleasant atmosphere, but are in no way exceptional. There are neither magnificent browsing rooms nor romantic ivory towers. 'The situation at Bard is worse: The library is located in a Greek temple because the donor of the building loved classic architecture. Unfortunately, there is nothing less attractive for leisurely reading than an enormous room that receives its bit of light only from the sky. None of the three progressive colleges tries to push the circulation by introducing dormitory libraries or developing an undue number of departmental libraries. A few of the latter, on the other hand, may be indispensable for carrying out the 
educational program effectively. Sarah Lawrence has placed about one thousand books in the science laboratories, and the music building houses the library collection of records and scores. At Bard, because of the general inadequacy of the main library building, more branches were developed. A sizable science library serves the students working in the laboratories, Close to the art studios, there was established an art and music library four years ago. In a pleasant room, art books and reproductions are displayed and music records may be used. This has become a rather popular place with the students who like to look at the beautiful Carnegie art set or to listen to the great music of the past. This kind of appreciation, however, does not do much to boost the circulation figures. Bard has classroom collections only in the modern language departments; they are fulfilling their purpose there to a considerable extent.

\section{Progressive Methods of Instruction}

Since neither the quality of the book collections nor their arrangement would go far to explain the wide reading of even the average student in progressive colleges, one may safely conclude that the laurel belongs to their methods of instruction. How may these be characterized in a few sentences? In the three institutions there is no preconceived curriculum for everybody; the needs of each individual student are taken into account and his initiative is strengthened by all possible means. A recent bulletin of Bard College says:

A student is not merely a passive listener in a class nor a mere reciter of lessons. He is urged to take his education into his own hands, to follow up his own questionings and to go as fast and as far as he can. The good student is not held down to the average rate of the class.... The aim is to give every student the highest degree of training he can take.

There are no required courses. Even the freshmen meet in small informal seminars. These are supplemented by individual conferences which each student has with each of his instructors. Such conferences are usually held bi-weekly. The instructor has here a splendid opportunity to arouse a boy's enthusiasm for a great idea and a great book, and he can also check up on the actual achievement of the student in this conversation far better than in any written examination. Any student who has a minimum of self-respect will hate to come to such a conference unprepared, and he will not go away from it without having received some new hint about the treasures of wisdom stored in the college library. Very often such a conference begins in the instructor's office, but ends in the stacks of the library. The highest degree of individualization is reached in the tutorials; here the professor deals only with one student on a subject in which the boy shows serious interest and ability. Even the freshman is now to have such a tutorial in his major field of study. Needless to say this type of education is expensive. At Bard there is now one instructor for every four students! The faculty members are extremely busy in spite of this unusually low ratio, for they are charged with wide responsibilities in guidance that really never end.

\section{The Librarian as Educator}

What is the position of the librarian in this educational setup? It would seem to be stronger than in the conservative college, since the progressive method of instruction tends to make students bookconscious. At Bard, the librarian is not just a member of the "staff," but his main 
function is that of an educator. In his rather few hours of leisure, he teaches also. He is a regular member of the German department, but has taught also in the history department. Branscomb, himself a director of libraries and a professor, has discussed with much wisdom the pro and con of the librarian as instructor in his Teaching with Books. From my own experience I can only state that a librarian who has done some teaching in his college will appreciate better what sort of books are useful for instructional purposes than his colleague who sees students only in his office or near the reference desk.

The informality of the whole educational work is reflected also in the library methods. There is no prescribed course in how to use the library. At Bard, at Bennington, and at Sarah Lawrence each freshman has at the beginning of the academic year an individual conference with the librarian to establish the desirable personal contact. It is expected that each student will learn how to use the library when he (or she) will have actual problems to solve in handling the catalog, using the indexes, and exploring the collection. Then the library staff is ready to assist, and no effort will be spared to explain every necessary detail. Two students working on the same problem may get very different recommendations, each of them according to his capability. This individualized reference work supplements the efforts that the instructors make in conferences and tutorials. It contributes indirectly also to the high circulation figures, since in the course of such conversations the student's attention is called to many books which he otherwise might have overlooked. There is nothing more rewarding for the library staff than these informal discussions. They usually cover not only questions of how to use the library, but also many other aspects of liberal education and college life. Between some students, particularly the older student assistants, and the library staff a friendship has grown up that has outlasted the day of graduation.

\section{Close Cooperation with the Faculty}

The personal collaboration of the librarian with the faculty is at least as close as are his contacts with the student body. For in the experimental college it is even more true than in other educational institutions that the well-informed instructor is the most effective agent the library has at its disposal. Since the faculties in all three progressive colleges of the East are not large, there is no need for having library committees. Most questions can be settled immediately and amiably in personal conversation between instructor and librarian, be it in the library, on the sidewalks of the campus, or in the evening by the fireside. There is a constant give and take. Most faculty members help by their expert advice in building up the collection. Their suggestions are gladly accepted, whether they come from a senior professor or from an instructor who has just finished his graduate work. In fact a nucleus of younger scholars, whose enthusiasm is still unbroken, gives the most gratifying cooperation. They are the unofficial library committee that meets day by day. On the other hand, the library staff supports their educational work in many ways, for instance, by assisting them in the preparation of syllabi, and by calling their attention to recent literature in their own fields of interest. We do not want to "teach" them anything; we strive for their sympathy and friendship. The observation of Branscomb "that the natural 
enemy of the librarian has always been the professor" does not apply in these progressive colleges.

The flexibility that is so characteristic of our work as a whole, may be found also in the handling of the book budget. There are no fixed appropriations to the departments. The money is spent where it is needed most; that is, where serious gaps are to be filled, where literature for newly designed courses is to be gathered, and where an old topic is approached from an unfamiliar angle. It must be repeated here: progressive education is expensive. The library at Bard has to buy many books even if no large circulation may be expected for them. Often items are purchased to suit the legitimate needs of only two or three persons on the campus. Duplicates are seldom acquired, since they are as a rule not needed in individualized education, and only a few inevitable textbooks are added occasionally, because the whole conception of the textbook is incompatible with the spirit of progressive teaching methods. The emphasis in acquisitions is upon material that is likely to have permanent value. At Bennington the policy is somewhat different; current publications, particularly in the social sciences, are purchased if they seem useful for the time being, even though they may have to be discarded after a while. A considerable amount of our money is devoted to good general reading, but even these books are usually selected with some educational purpose in mind. We try to get as many recent thought-provoking books as possible and to stimulate interest by having some elaborate exhibits, but we never lose sight of the fact that the wholehearted pursuit of his studies is more important for the Bard boy than purely recreational reading could be.
Progressive methods of education cannot succeed if the spirit of liberality does not prevail everywhere on campus. Any Bard student may enter the laboratories and studios at any hour of the day or night he pleases. Although the library cannot go quite that far, we nevertheless keep very long hours and operate with a minimum of rules. Almost all the books, even those that most college libraries would consider to be reference works, and the bound periodicals, may go out for two weeks and are open to renewal. Books that are not in general demand often are lent for the whole semester, particularly to upperclassmen. Only a few new books are limited to seven-day loans for students and faculty alike.

\section{The Problem of Reserved Books}

Extensive use of reserved books may be a necessity in large institutions, but is certainly out of place in a small college which stresses individualized instruction. Bard College Library has enough material on most subjects so that each student can read a different book on the topic that is to be discussed in his seminar. Such a variety of reading will render possible a more stimulating exchange of opinions in class than if everybody.had used the same assigned work.

At first I tried teaching without any reserved books in a course of my own in English history. I worked out so comprehensive a syllabus that each of my fifteen students had plenty of literature available for each seminar meeting; the syllabus was supported by the individual advice given in the bi-weekly conferences. When I saw that it was not difficult to succeed with this method, I began to persuade faculty members to change their attitude. Some of them who were fully 
aware of our resources in their field cooperated at once and ceased to put books on reserve. The more conservative professors and those who had taught previously in very large institutions insisted on keeping a reserve. It took a long while to induce these faculty members to change their points of view. The first step was to suggest to them a differentiation between various types of reserved books according to their general importance to the whole class. The library introduced, in addition to the overnight reserve, the three-day and seven-day reserves. These gave the students a better chance really to read a book instead of hurrying through an assignment. And some of the professors finally recognized that a book that was a three-day, or seven-day reserve, could just as well go out as a regular book for two weeks. There is now unanimity among faculty members and students concerned, that under the Bard system of individualized instruction the educational results are better, if the number of reserved books is kept down to the rather few cases of real necessity.

\section{Reading Period and Senior Project}

Finally, a word must be said about two distinct features of Bard's educational program and how they affect the use of the book collection. One is the so-called "Winter Field and Reading Period." The students at Bard, and also Bennington, spend six to seven weeks after Christmas off campus. Many work in laboratories, business offices, or research institutions to get experiences that no small college campus could offer. Others spend their time at home or in large metropolitan libraries where they engage in some usually well-planned project of their own choice. The library at Bard helps them in preparing for the Reading Period and permits them to take as many library books with them as they think they may need for their task or would like to have for leisurely reading. The library staff has here a fine chance to offer suggestions to students for widening their general education.

More important, and more difficult, from the point of view of the library, is the Senior Project (or Senior Thesis, as it is called at Bennington). Each Bard student is expected to do in his senior year a piece of independent work, on which he is to spend at least one-fourth of his time. These projects may cover a rather wide field of related subjects or may be restricted research studies on one specific topic. Some of them have been truly excellent; they have paved for their authors the way to a job or a graduate fellowship. They seem to many an observer to be the finest proof of what individualized education may do for a talented boy. The librarian helps in planning the project, at least as far as its bibliographical aspect is concerned; and in a considerable number of cases, he has been also a member of senior project committees. He discusses with the student the literature that he may find in the college library. Usually only part of the books that are essential for carrying out the project will be available in the collection. Therefore the library buys those items that the student will need constantly, even though these monographs may be of only limited use to the college community as a whole. This is at times a drain on the book budget, but the librarian feels that he should give here the utmost assistance because of the educational value of the senior projects. In addition to these purchases, many important books are secured by interlibrary 
loan. Since Bard is affiliated with Columbia University, the cooperation of the Columbia Library is given generously. But often help will be received also from other libraries. The best example of liberality and understanding is offered by New York State Library. When one of the ablest Bard students decided to write his Senior Project on the history of $\boldsymbol{M c}$ Clure's Magazine, the State Library immediately agreed, in this exceptional case, to send to Bard the fifty-odd volumes that were needed. Sometimes, however, the task of getting the literature for the senior projects together becomes too heavy for the Bard Library, and the students are advised to do research in the metropolitan scholarly libraries. That in itself will be a useful experience for students who intend to go into graduate or professional schools. On the whole, the Senior Project brings about the crowning effort of the library to help in realizing the educational ideals of the college.

I have tried to describe here some phases of the work done in the libraries of the three Eastern progressive colleges in general, and experiments at Bard in particular. I am fully aware not only of our achievements, but also of our shortcomings and of the fact that some of the methods we use cannot be employed very easily in large institutions. But whatever faults there may be, these three libraries seem to be moving in the right direction. To quote once more from Branscomb: "If funds are limited and staffs are inadequate, it may be necessary to be less correct along formal lines in order to take an active part in the shift of the teaching program from reliance on formal instruction towards a greater faith in individual study." The libraries at Bard, Bennington, and Sarah Lawrence have taken this active part!

\section{The Task of the College Library}

\section{(Continued from page 4I)}

ers, methods, techniques, and processes whose only virtue is that they are so general in their character and so all-inclusive in their results that some little bit of usefulness is bound to be in them. If you shoot at a target with a shotgun, you are almost bound to hit it, and one of the shots may find the bull's-eye. But many of the shots will be wasted. A rifle with a sure aim is much more efficient.

The task of the college library, it seems to me, is to become a college library-not just a library in a college. The task of the college library is to find out; first, what it is for and for whom it exists and what its patrons need, not only in books, but in service; and then to devise ways to give these things. The ways may not be orthodox. There is little reason to suppose that they will be. The classification system may not be like any other on earth; the subject catalog may look very strange to a teacher of cataloging. But there is no essential virtue in orthodoxy when it is a question of service. The only valuable consistency is one that grows out of need, not one that grows out of practice. The college library is a highly specialized institution, giving a very special service for a special purpose to a special group. It will be a wonder indeed if the best means and methods for doing this do not turn out to be highly specialized as well. 